\title{
Mineralna ulja u ulozi adjuvansa u veterinarskim cjepivima
}

\author{
K. Vretenar Špigelski* E. Perak Junaković, K. Šandor, A. Vujnović, \\ S. Sinković, I. Žarković, D. Fajdić i S. Terzić
}

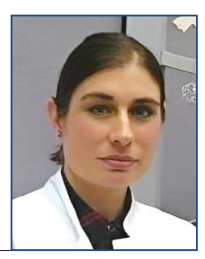

\section{Sažetak}

$\mathrm{U}$ veterinarskoj medicini cjepiva imaju presudnu ulogu u očuvanju zdravlja životinja. Napretkom znanosti djelatne tvari u cjepivima nisu više samo cijeli mikroorganizmi (inaktivirani ili atenuirani), već se razvijaju cjepiva koja sadržavaju dijelove mikroorganizama (rekombinirani proteini ili sintetski peptidi) dobivena različitim naprednim tehnologijama. $\mathrm{Na}$ taj je način osiguran daleko veća neškodljivosti cjepiva, a njegova imunogenost nastoji postići dodatkom adjuvansa. Uz adjuvanse $u$ obliku aluminijevih soli, a koji su u uporabi već desetljećima i prvi po zastupljenosti $\mathrm{u}$ veterinarskim cjepivima, značajni su $\mathrm{i}$ adjuvansi $\mathrm{u}$ obliku emulzija, a između ostalih i mineralna ulja. Negativna strana primjene mineralnih ulja može biti pojava lokalne reakcije na mjestu primjene. Ovakve promjene mogu $\mathrm{u}$ tovnih životinja utjecati na klaoničku vrijednost, a u izložbenih životinja prilikom natjecanja ili izložbi na ocjenu. Zbog navedenih lokalnih reakcija koje mogu izazvati i otežane primjene zbog viskoznosti, mineralna ulja nisu često korišteni adjuvans u cjepivima namijenjenim ljudima i kućnim ljubimcima, već se uglavnom koriste za cijepljenje farmskih životinja. Razvojem novih tehnologija $u$ proizvodnji nastoji se umanjiti negativan utjecaj na životinje, kao i moguće reakcije u osoba koje primjenjuju takva cjepiva, stoga uputa za cjepivo koje sadržava mineralno ulje mora sadržavati upozorenje tijekom primjene o rizicima koji mogu nastati i upute postupanja u slučaju reakcije.

Ključne riječi: mineralna ulja, inaktivirana veterinarska cjepiva, adjuvansi

\section{Uvod}

Adjuvansi su, uz djelatne tvari, nužni sastojci u inaktiviranim cjepivima virusnog ili bakterijskog podrijetla, a dodaju u cjepiva da bi se pojačao

imunosni odgovor u cijepljenih životinja (Anonymous, 1998.). U novije vrijeme se kao djelatne tvari umjesto cijelog živog ili inaktiviranog mikroorganizma

Katja VRETENAR ŠPIGELSKI*, dr. med. vet., stručna suradnica, (dopisni autor, e-mail: vretenar@veinst. hr), Eleonora PERAK JUNAKOVIĆ, mag. chem., asistentica, dr. sc. Ksenija ŠANDOR, dipl. ing. kem., znanstvena suradnica, Anja VUJNOVIĆ, dr. med. vet., viša stručna suradnica, Sonja SINKOVIĆ, dr. med. vet., stručna suradnica, dr. sc. Irena ŽARKOVIĆ, dr. med. vet, asistentica, Dominika FAJDIĆ, dr. med. vet., stručna suradnica, dr. sc. Svjetlana TERZIĆ, dr. med. vet., izvanredna profesorica, znanstvena savjetnica u trajnom zvanju, Hrvatski veterinarski institut, Zagreb, Hrvatska 
često koriste rekombinirani proteini ili sintetski peptidi. Inaktivacija antigena, kao i uporaba pročišćenih subjediničnih antigena, osigurava veću sigurnost cjepiva, ali u nekim slučajevima takva cjepiva potiču slabiji imunosni odgovor od sličnih cjepiva koja sadržavaju atenuirane mikroorganizame (Aucouturier i sur., 2001., Singh i O'Hagan 2003., Heldens i sur., 2008.). Izbor adjuvansa, osim o svojstvima i specifičnosti antigena te životinjskoj vrsti kojoj je cjepivo namijenjeno, ovisi i o načinu primjene te o tipu imunosti koji je potrebno potaknuti (Spickler i Roth, 2003.).

Uporaba adjuvansa $u$ veterinarskim cjepivima regulirana je brojnim smjernicama regulatornih tijela te $\mathrm{u}$ Europskoj i $\mathrm{u}$ nacionalnim farmakopejama. Najznačajnije smjernice, propisi i vodiči su, uz farmakopeju i:

Vodič o uporabi adjuvansa u veterinarskim cjepivima (Anonymous, 2018.),

- Direktiva 2001/82/EZ, (Anonymous, 2001.),

Uredba (EU) 2019/6 Europskog parlamenta i Vijeća od 11. prosinca 2018. o veterinarsko-medicinskim proizvodima i stavljanju Direktive 2001/82/EZ, izvan snage (Anonymous, 2019.),

- Vodič o adjuvansima u cjepivima (Anonymous, 2004.),

- Uredba Komisije (EZ) br. 37/2010 od 22. 12. 2009. o farmakološki djelatnim tvarima i njihovoj klasifikaciji u odnosu na dopuštene količine rezidua $\mathrm{u}$ hrani životinjskog podrijetla (Anonymous, 2009.),

- Vodič o sigurnosti primjene imunoloških veterinarsko-medicinskih proizvoda (Anonymous, 2007.),

- Monografija 0062 Europske Farmakopeje: Cjepiva za primjenu $\mathrm{u}$ veterini (Anonymous, 2020.a).
Najčešći adjuvansi koji se nalaze $u$ sastavu veterinarskih cjepiva su aluminijeve soli koje su u uporabi još od tridesetih godina prošlog stoljeća. Od 1990. godine do danas su sve češće u sastavu cjepiva noviji adjuvansi, (Christensen, 2016.), između ostalih i mineralna ulja. Mineralna se ulja koriste u kombinaciji s nereaktivnim antigenom (npr. pročišćenim proteinima ili sintetskim peptidima) te prije svega u cjepivima za goveda, male preživače, perad i ribe i to u slučajevima kada je nužno postići dugotrajni imunosni odgovor, bez potrebe za docjepljivanjem (Aucouturier i sur., 2001.). Zbog neželjenih učinaka, mineralna ulja su rijetko u sastavu cjepiva namijenjenih ljudima i kućnim ljubimcima (Spickler i Roth, 2003.). Njihova djelotvornost se istražuje u svrhu liječenja karcinoma, malarije, AIDS-a i autoimunosnih bolesti namijenjenih ljudima te $u$ cjepivima koja su u fazi kliničkih ispitivanja (Saul i sur., 2005., Shah i sur., 2015., De Souza Apostólico i sur., 2016.).

Budući da se mineralna ulja koriste ponajprije $\mathrm{u}$ veterinarskim cjepivima te postoji opasnost prilikom njihove primjene, svrha ovog preglednog članka je upoznati doktore veterinarske medicine $\mathrm{s}$ prednostima i rizicima koje nosi primjena takvih cjepiva te ih potaknuti da pozorno prouče uputu o veterinarsko-medicinskom proizvodu, osiguraju se od mogućeg samoinjiciranja ili nehotičnog injiciranja takvog cjepiva pomoćniku te ih uputiti o postupcima koje moraju provesti u slučaju nezgode.

Pregledom sastava cjepiva odobrenih u Republici Hrvatskoj, uočeno je da i dalje većina cjepiva sadržava adjuvanse u obliku aluminijevih soli, dok se mineralna ulja koriste $\mathrm{u}$ pojedinim inaktiviranim virusnim i bakterijskim cjepivima protiv zaraznih bolesti svinja, goveda, peradi i riba. Uglavnom su to inaktivirana cjepiva koja sadrže mineralna ulja kategoriziranih kao emulzije za injekciju (Anonymous, 2020.b). 


\section{Mineralna ulja - adjuvansi na bazi emulzija}

Mineralna ulja su po fizikalno kemijskim karakteristikama emulzije. Definicija emulzije glasi: „Disperzni sustavi, sastavljeni od dviju tekućina (faza), lipofilne (npr. mineralno ulje) i hidrofilne (npr. voda), koje se međusobno ne miješaju." U sastavu emulzije je nužan sastojak surfaktant (emulgator), koji omogućuje stabilnost disperzija navedenih tekućina (Pavlović, 2019.). U sastavu cjepiva te faze su voda (medij za antigen) i ulje (Acounter, 2001.). S obzirom na zastupljenost pojedine faze, emulzije se dijele na: emulzije ulje/voda (engl. oil in water $\mathrm{O} / \mathrm{W}$ ); emulzije voda/ulje/voda; (engl. water/oil/water, $W / O / W$ ) i emulzije voda/ulje (engl. water in oil $\mathrm{W} / \mathrm{O})$.

Emulzije ulje/voda (engl. oil in water O/W) sadržavaju mikrokapljice ulja u vodi, emulzije voda/ulje/voda (engl. water/oil/water, $\mathrm{W} / \mathrm{O} / \mathrm{W}$ ) sadržavaju mikrokapljice vode u ulju, dispergirano u vodenoj fazi, a emulzije voda/ulje (engl. water in oil W/O) sadržavaju mikrokapljice vodene faze u ulju (Spickler i Roth, 2003., Shah i sur., 2015.). U ovu posljednju skupinu svrstana su i mineralna ulja.
Emulzije su 1916. godine opisali Lemoinic i Pinoy, ali Jules Freund je sredinom 30-ih godina 20. stoljeća prvi razvio koncept emulzije (Acounter, 2001.). Freund je razvio adjuvans na principu vode $\mathrm{u}$ ulju, nazvan Freundov kompletni adjuvans (engl. Freund' Complete Adjuvant, FCA), koji je sadržavao i inaktivirane mikobakterije, kao dodatni imunomodulator (Vogel, 2000.). FCA sadržava 85 do $90 \%$ ulja (mineralno ulje, skvalen ili skvalan), 10 do $15 \%$ manidmonooleata emulgatora (npr. Arlacel A) i $500 \mu \mathrm{g}$ toplinom inaktiviranih mikobakterija (najčešće M. tuberculosis). Freudov kompletni adjuvans je "zlatni standard" kada se radi o emulzijama voda/ulje koji potiče jak imunosni odgovor, ali je i vrlo reaktivan te se danas ne koristi u praksi. Nedugo nakon razvoja FCA razvijen je i Freundov nepotpuni adjuvans (engl. Freund's Incomplete Adjuvant, IFA), koji je istog sastava, ali ne sadržava inaktivirane mikobakterije, a i manje je toksičan (Lindblad, 2000., Vogel, 2000., De Souza Apostólico i sur., 2016.)

$\mathrm{Na}$ početku razvoja adjuvansa na bazi emulzija nedostatci su im bili nestabilnost emulzije i relativno velika

Tabela 1. Prednosti, način djelovanja i nedostatci mineralnih ulja (Aucouturier, 2001., Cox i Coulter, 1997., Spickler i Roth, 2003.J

\begin{tabular}{|c|c|c|}
\hline \multicolumn{3}{|c|}{ Mineralna ulja } \\
\hline Prednosti & Način djelovanja & Nedostatci \\
\hline $\begin{array}{l}\text { - Potiču jak i dugotrajan } \\
\text { imunosni odgovor } \\
\text { - } \quad \text { Isplativa su (manja } \\
\text { doza antigena, manja } \\
\text { učestalost primjene, } \\
\text { prikladno za cijepljenje } \\
\text { farmskih životinja) }\end{array}$ & $\begin{array}{l}\text { - } \quad \text { Stvaraju depoe (sporo } \\
\text { otpuštaju antigen s } \\
\text { mjesta primjene) } \\
\text { _ } \quad \text { Induciraju citotoksične } \\
\text { limfocite } \\
\text { - } \quad \text { Djeluju kao slab } \\
\text { imunomodulatori }\end{array}$ & $\begin{array}{l}\text { - Pojava lokalnih reakcija, } \\
\text { često dugotrajnih i } \\
\text { bolnih } \\
\text { _ } \quad \text { u ljudi prilikom } \\
\text { samoinjiciranja i u } \\
\text { životinja } \\
\text { - Viskozne, teže se } \\
\text { injiciraju } \\
\text { Ograničena primjena u } \\
\text { cjepivima namijenjenim } \\
\text { ljudima ili kućnim } \\
\text { ljubimcima }\end{array}$ \\
\hline
\end{tabular}


viskoznost. Jako viskozne emulzije često su nakon primjene prouzročile izražene lokalne reakcije nakon primjene. Kasnije su nastale emulzije koje su stabilnije i manje viskozne (Dalsgaard i sur., 1990.).

Mineralna se ulja dugo zadržavaju na mjestu primjene, čak više od deset mjeseci, a uglavnom ih uklone makrofagi. Međutim, mogu se djelomično metabolizirati u masne kiseline, trigliceride, fosfolipide i sterole. Manji dio mineralnih ulja tijekom 30 dana nakon primjene nestaje s mjesta primjene i tada se mogu naći $u$ jetri i masnim tkivima u obliku fosfolipida i masnih kiselina (Bollinger, 1970.).

\section{Mehanizam djelovanja mineralnih ulja}

Mehanizam djelovanja adjuvansa općenito pa tako ni mineralnih ulja, nije u potpunosti poznat. Budući da primjena cjepiva potiče cijeli niz odgovora organizma, teško je odrediti koji je prvi korak djelovanja adjuvansa (Schijns, 2000., Singh i O'Hagan, 2003.). Mineralna ulja posreduju između antigena i imunosnog sustava na jedan od sljedećih načina (Cox i Coulter, 1997., Biliau i Matthys, 2001., Spickler i Roth, 2003., Petrovsky i Aguilar, 2004.):

- kao imunomodulatori: slabi su imunomodulatori, slabo potiču stanični i humoralni imunosni odgovor

- indukcijom citotoksičnih limfocita: potiču citotoksične T-limfocite na odgovor, direktnim vezanjem peptida na površinu stanice (MHC-1)

stvaranjem "kratkotrajnih depoa" koji usporavaju otpuštanje antigena s mjesta primjene, te se na taj način izravno uključuju u imunosni odgovor organizma te potiču humoralnu imunost.

\section{Mjere zaštite prilikom} primjene cjepiva s mineralnim

\section{uljima}

\section{Neželjeni učinci nakon primjene na životinjama}

Primjena mineralnih ulja u cjepivima, uz navedene prednosti na učinkovitost cjepiva, može imati i štetne posljedice, a koje se najčešće očituju lokalno na mjestu primjene. U tovnih životinja lokalne reakcije nakon cijepljenja mogu imati i negativan ekonomski učinak (npr. smanjena kvaliteta mesa) (Roth, 1999.). Važno je uočiti je li lokalna reakcija nakon cijepljenja nastala kao posljedica nestručne primjene, odnosno primjene koja nije u skladu s opisanim u uputi o veterinarsko-medicinskom proizvodu ili je prouzročena mineralnim uljem $u$ cjepivu. Osim reakcije na adjuvans, moguća je pojava reakcije na mjestu primjene prouročene drugim čimbenicima (unos mikroorganizama kontaminiranom iglom, kontaminacija cjepiva, reakcije preosjetljivosti, trauma tkiva te krvarenje) (Heegaard i sur., 2011.).

\section{Upozorenja za osobe koje primjenjuju cjepiva s mineralnim uljima}

U slučaju da osoba koja primjenjuje cjepivo životinji slučajno primjeni cjepivo sebi ili pomoćniku može se razviti dugotrajna lokalna reakcija. Ukoliko je sadržaj injiciran u tetivu ili zglob, mineralna ulja stvaraju pritisak na krvne žile i živce pa dolazi do komplikacija u zahvaćenoj regiji, dok sadržaj injiciran u meko tkivo, može izazvati upalnu reakciju koja može dovesti i do nekroze (O'Neill i sur., 2005.a, Jennissen i sur., 2011., Meyer i sur., 2018.). Na mjestu primjene karakteristične su kronične granulomatozne upalne reakcije uz formiranje sterilnih apscesa, koje mogu zahtijevati kiruršku obradu 
(da bi se uklonilo ulje) te primjenu kortikosteroida (Jones, 1996.). Čak i mala količina mineralnog ulja iz cjepiva koje je "zarobljeno" u prostoru omotača fleksora može prouzročiti kompresiju na žile i živce zahvaćenog prsta (O'Neill i sur., 2005.a). Rano poduzete mjere, debridement $i$ ispiranje tog područja te dekompresija vjerojatno će dati najbolji rezultat. Međutim, nakon prvog postupka potrebni su česti pregledi i ponavljanje navedenih postupaka (O'Neill i sur., 2005.b).

Zbog navedenih rizika za svako cjepivo koje sadržava mineralno ulje treba u uputi biti navedeno upozorenje o posljedicama nehotičnog injiciranja osobama koje cijepe ili pomažu prilikom cijepljenja.

Važno je napomenuti da je ponekad u sažetku opisa svojstava proizvoda (engl. Summary of Product Characteristics) i u uputi o veterinarsko-medicinskom proizvodu mineralno ulje navedeno kao parafin, tekući ili lagani tekući parafin, ponekad kao "mineralno ulje", a ponekad je navedeno tržišno ime (npr. Montanide ISA 25 VG, Seppic ISA 70 ulje) (Anonymous, 2017.). U svakom slučaju, upozorenje korisniku i liječniku mora biti navedeno.

Tekst sažetka svojstava proizvoda, označavanja (etikete) i upute o VMP-u za cjepiva koja sadržavaju mineralno ulje je standardni tekst naveden u QRD-u (engl. Quality Review of Documents veterinary product), verzija 8.2,01/2021 (Anonymous, 2021.):

\section{Upute korisniku}

Ovaj veterinarsko-medicinski proizvod sadrži mineralno ulje. Nehotična injekcija/samo injiciranje može prouzročiti jaku bol i oticanje, naročito ako se injicira u zglob prsta, a u rijetkim slučajevima ukoliko nije pružena hitna medicinska pomoć može rezultirati gubitkom zahvaćenog prsta. Ukoliko ste se nehotično injicirali ovim veterinarsko-medicinskim proizvodom, potražite hitnu medicinsku pomoć, čak ako je injicirana vrlo mala količina. Sa sobom ponesite uputu o VMP. Ako bol potraje više od 12 sati nakon liječničkog pregleda, ponovo potražite pomoć liječnika.

\section{Upute liječniku}

Ovaj veterinarsko-medicinski proizvod sadrži mineralno ulje. U slučaju nehotičnog injiciranja ovim proizvodom, čak ako je injicirana i vrlo mala količina, može prouzročiti intenzivno oticanje, koje može rezultirati ishemičnom nekrozom, a čak i gubitkom prsta. HITNO je potreban, stručni kirurški pregled koji može zahtijevati preventivnu inciziju i ispiranje injiciranog područja, napose $u$ području jagodice prsta ili tetiva.

Prema monografiji 0062 Europske farmakopeje: Cjepiva za primjenu $u$ veterini (engl. Vaccines for veterinary use) na etiketi cjepiva koje sadržava mineralno ulje mora biti navedeno upozorenje da je u slučaju samoinjiciranja nužno potražiti hitnu liječničku pomoć (Anonymous, 2020.a).

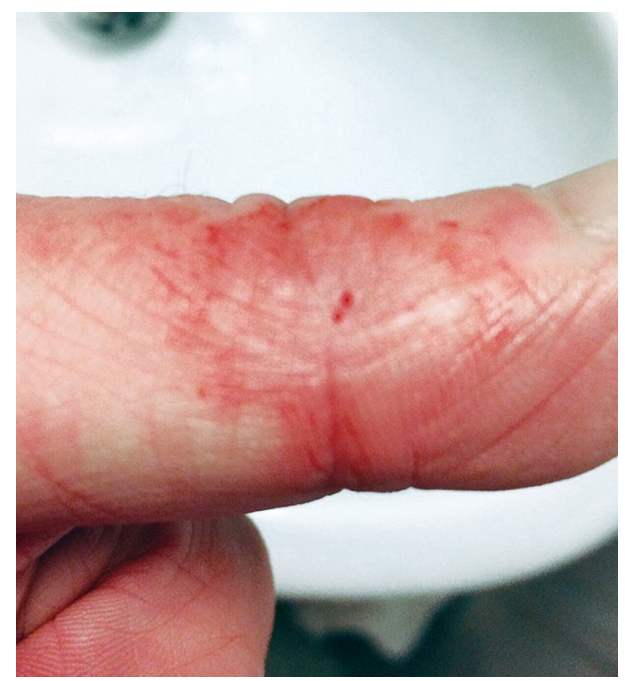

Slika 1. Lokalna reakcija nakon samoinjiciranja cjepiva za ribe koje sadržava mineralno ulje (Aas i Rǿ, 2019.) 
U uputi o VMP-u, u dijelu o nuspojavama treba biti naveden i detaljni opis moguće lokalne reakcije na mineralno ulje. Ovaj dio upute uključuje podatke o učestalosti, očekivanom trajanju i mogućim reakcijama dobivenim na temelju provedenih studija. To je posebno važno naglasiti kada se radi o životinjama koje se uzgajaju za prehranu. Lokalne reakcije na mineralno ulje su bolne i dugotrajne (Edelman, 2002.).

\section{Budućnost i alternative primjeni mineralnih ulja}

Alternativa primjeni mineralnih ulja $\mathrm{u}$ ulozi adjuvansa $\mathrm{u}$ veterinarskim cjepivima je primjena već postojećih ili novih adjuvansa (Cox i Coulter, 1997., Spickler i Roth, 2003., Anonymous, 2004., Pavlović, 2019.):

- drugih oblika adjuvansa na bazi emulzija:

- ulje u vodi (O/W), koji je dobro podnošljiv adjuvans, ali potiče kratkotrajnu imunost $\mathrm{u}$ odnosu na emulziju tipa voda u ulju;

- voda/u ulju/u vodi (W/O/W) po brzini otpuštanja antigena je između ova dva tipa emulzije, može potaknuti i kratkotrajnu i dugotrajnu imunost i manje su štetna od emulzija voda $\mathrm{u}$ ulju (Marcy, 1997., Aucorturier i sur., 2001.)

aluminijevih soli,

saponina,

- imunostimulacijskih kompleksa (engl. Immune stimulating complexes, ISCOMs),

- liposoma,

- nano i mikročestica,

- citokina,

- deriviranih polisaharida,

- neionskih blok kopolimera,

- kombinacije više adjuvansa

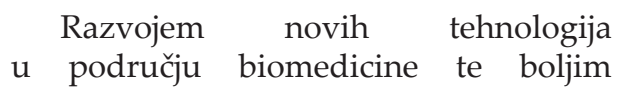

razumijevanjem imunosnih mehanizama i svojstava antigena, postavljeni su temelji za razvoj novih adjuvansa. Usavršavanje postojećih i razvoj novih cjepiva vezan je s paralelnim razvojem adjuvansa. (Anonymous, 2004.).

Sve se više javlja potreba za razvojem novih adjuvansa, koji će biti učinkovitiji, a istovremeno i sigurniji za primjenu te postali alternativa mineralnim uljima i aluminijevim solima. To bi se moglo postići primjenom novih generacija adjuvansa, koji bi se razlikovali po sastavu, mehanizmu djelovanja i neželjenim učincima koje bi mogli izazvati (Spickler i Roth, 2003.).

Osim navedenog, moguće je i kombinirati dva ili više adjuvansa $\mathrm{u}$ cjepivu. Dodatkom imunosnih potencijatora $u$ adjuvansima na bazi emulzije, može se potaknuti jači imunosni odgovor zasnovan na reakciji T-stanica, što je trenutno $u$ istraživanju. Ipak, prije primjene dodatnog adjuvansa ili proizvodnje novog, treba razmotriti primjenu već dobro poznatih adjuvansa (Shah i sur., 2015.).

\section{Zaključak}

Mineralna ulja u ulozi adjuvansa $u$ inaktiviranim cjepivima namijenjenim farmskim životinjama osiguravaju dugotrajnu imunost te su takva cjepiva ekonomski isplativa. Glavni nedostatak mineralnih ulja je mogućnost pojave lokalne reakcije nakon primjene na životinjama, odnosno prilikom nehotičnog samoinjiciranja osobe koja primjenjuje cjepivo. Bolje razumijevanje mehanizama djelovanja pojedinih adjuvansa, uključujući i mineralna ulja, olakšati će razvoj novih adjuvansa i novih cjepiva.

\section{Literatura}

1. AAS, O. and G. RǾ (2019): Self-injection injury during vaccination of salmon. Tidsskr Nor Laegeforen 139, doi: 10.4045/tidsskr.18.0653. (In Norwegian). 
2. Anon. (2018): Guideline on the use of adjuvanted veterinary vaccines. EMEA/CVMP/ IWP/315887/2017, 21.06.2018.

3. Anon. (2001): Direktiva 2001/82/EZ Europskog parlamenta i Vijeća od 06.11.2001. o zakoniku Zajednice o veterinarsko-medicinskim proizvodima. Službeni list Europske unije 13/Sv. 30, 28.11.2001.

4. Anon. (2019): Uredba (EU) 2019/6 Europskog parlamenta i Vijeća od 11. prosinca 2018. o veterinarsko-medicinskim proizvodima i stavljanju izvan snage Direktive 2001/82/EZ. Službeni list Europske unije L 4/62, 7.1.2019.

5. Anon. (2004): Guideline on Adjuvants in vaccines, EMEA/CPMP/VEG/17/03/2004v 5/Consulation, 25.03.2004.

6. Anon. (2010): Uredba Komisije (EZ) br. 37/2010 od 22. 12. 2009. o farmakološki djelatnim tvarima i njihovoj klasifikaciji u odnosu na dopuštene količine rezidua u hrani životinjskog podrijetla. Službeni list Europske unije 03/Sv.32, 20.01.2010.

7. Anon. (2007): Guideline on user safety for immunological veterinary medicinal products, EMEA/CVMP/IWP/54533/2006, 23.04.2007.

8. Anon. (2020a): European Pharmacopoeia, $10^{\text {th }}$ edition. Strasbourg: Directorate for the Quality of Medicines and HealthCare of the Counicl of Europe

9. Anon. (2020b): Uprava za veterinarstvo, baza veterinarsko-medicinskih proizvodaa, http://www. veterinarstvo.hr/default.aspx?id=140, podatci ažurirani 01.02.2021., pristup: 10.02.2021

10. Anon. (2021): QRD, version 8.2, EMEA, 01/2021

11. Anon. (2017): Oily injections what you need to know to keep safe. https://www.veterinaryprescriber.org/ oily-injections-what-you-need-to-know-to-keepsafe (Veterinary Prescriber, pristup 25.08.2020.)

12. AUCOUTURIER, J. L. DUPUIS, V. GANNE (2001): Adjuvants designed for veterinary and human vaccines. Vaccine 19, 2666-2672.

13. BILIAU, A. and P. MATTHYS (2001): Modes of action of Freund's adjuvants in experimental models of autoimune diseases. J. Leukoc. Biol. 70, 849-860.

14. BOLLINGER, J. N. (1970): Metabolic Fate of Mineral Oil Adjuvants Using ${ }^{14} \mathrm{C}$-Labeled Tracers I: Mineral Oil. J. Pharm. Sci. 59, 1084-1088.

15. CHRISTENSEN, D. (2016): Vaccine Adjuvant: Why and how. Hum. Vaccines Immunother. 12, 27092711.

16. COX, J. C. and A. R. COULTER (1997): Adjuvants a classification and review of their modes of action. Vaccine 15, 248-256.

17. DALSGAARD, K., L. HILGERS and G. TROUVE (1990): Classical and new approaches to adjuvant use in domestic food animals. Adv. Vet. Sci. Comp. Med. 35, 121-128

18. DE SOUZA APOSTÓliCO, J., V. ALVES SANTOS LUNARDELLI, F. C. COIRADA, S. B. BOSCARDIN and D. SANTORO ROSA (2016): Adjuvants: Classification, Modus Operandi, and Licensing. J. Immunol. Res. 2016:1459394. doi: $10.1155 / 2016 / 1459394$.
19. EDELMAN, R. (2002): The Development and Use of Vaccine Adjuvants. Mol. Biotehnol. 21, 129-148.

20. HEEGAARD, P. M. H., L. DEDIEU, N. JOHNSON, M. F. Le POTIER, M. MOCKEY, F. MUTINELLI, T. VAHLENKAMP, M. VASCELLARI and N. S. SØRENSEN (2011): Adjuvants and delivery system in veterinary vaccinology: current state and future developments. Arch. Virol. 156, 183-202.

21. HELDENS, J. G. M., J. R. PATEL, N. CHANTER, G. J. TEN THIJ, M. GRAVENDIJCK, V. E. SHIJNS, A. LANGEN and TH. P. M. SCHETTERS (2008): Veterinary vaccine development from an industrial perspective. Vet. J. 178, 7-20.

22. JENNISSEN, C., J. WALLANCE, K. DONHAM, et al. (2011): Unintentional needlestickinjuries in livestock production: A case series and review. J. Agromedicine 16, 58-71.

23. JONES, D. P. (1996): Accidental Self inoculation With Oil Based Veterinary Vaccines. N. Z. Med. J. 109, 363-365.

24. LINDBLAD, E. B. (2000): Freund's adjuvants. In: Vaccine Adjuvants: Preparation Methods and Research Protocols. Springer, Totowa, NJ (vol 42, 49-63.).

25. MARCY, D. W. (1997): Vaccine adjuvants. Sem. Vet. Med. Surg. (Small Anim) 12, 206-211.

26. MEYER, G., F. JEGOU, J. F. HAMEL and D. BOELS (2018): Risk linked to accidental inoculation of humans with veterinary vccines: a 7 -year prospective study. Clin. Toxicol. 56, 825-855.

27. O'NEILL, J. K., S.W. RICHARDS, D. M. RICKETTS, M. H. PATTERSON (2005b): The effects of injection of bovine vaccine into a human digit: a case report. Environ. Health 4:21.

28. O' NEILL, A. C., T. S. ISMAEL, J. MCCANN, P. J. REGAN (2005a): Fish vaccine injection injuries of the hand. Br. J. Plast. Surg. 58, 547-549.

29. PAVLOVIĆ, A. (2019): Regulatorni zahtjevi u ispitivanju virusnih onečišćenja u proizvodnji cjepiva, Završni specijalistički, Sveučilište u Zagrebu, Farmaceutsko-biokemijski fakultet; Sveučilište u Zagrebu, Farmaceutsko-biokemijski fakultet, citirano: 26.02.2021., https://urn.nsk.hr/ urn:nbn:hr:163:733729

30. PETROVSKY, N. and J. C. AGUILAR (2004): Vaccine adjuvants: Current state and future trends. Immunol. Cell. Biol. 82, 488-496, Wiley Online Library, https://onlinelibrary.wiley.com/ toc/14401711/2004/82/5

31. ROTH, J. A. (1999): Mechanistic Bases for Adverse Vaccine Reactions and Vaccine Failures. Adv. Vet. Med. 41, 681-700.

32. SAUL, A., G. LAWRENCE, A. ALLWORTH, et al. (2005): A human phase 1 vaccine clinical trial of the Plasmodium falciperum malariia vaccine candidate apical membrane antigen 1 in Montanide ISA720 adjuvant. Vaccine 23, 3076-3083.

33. SCHIJNS, V. E. (2000): Immunological concepts of vaccine adjuvant activity. Curr. Opin. Immunol. 12, 456-463. 
34. SINGH, M. and D. T. O'HAGAN (2003): Recent advances in veterinary vaccine adjuvants. Int. J. Parasitol. 33, 469-478.

35. SHAH, R. R., L. A. BRITO, D. T. O'HAGAN and M. M. AMIJI (2015): Emulsions as Vaccine Adjuvants. In: Foged, C., T. Rades, Y. Perrie, S. Hook: Subunit Vaccine Delivery. Springer, New York (59-76).
36. SPICKLER, A. R. and J. A. ROTH (2003): Adjuvants in veterinary vaccines: Modes of action and adverse effects. J. Vet. Intern. Med. 17, 273-281.

37. VOGEL, F. R. (2000): Improving Vaccine Performance with Adjuvants. Clin. Infect. Dis. 30, S266-S270.

\section{Mineral oils as adjuvants in veterinary vaccines}

Katja VRETENAR ŠPIGELSKI, DVM, Expert Associate, Eleonora PERAK JUNAKOVIĆ, mag. chem., Assistant, Ksenija ŠANDOR, PhD, Research Associate, Anja VUJNOVIĆ, DVM, Senior Expert Associate in Science, Sonja SINKOVIĆ, DVM, Expert Associate, Irena ŽARKOVIĆ, DVM, PhD, Assistant, Dominika FAJDIĆ, DVM, Expert Associate, Svjetlana TERZIĆ, DVM, PhD, Senior Scientific Adviser in Tenure, Associate Professor, Croatian Veterinary Institute, Zagreb, Croatia

In veterinary medicine, vaccines play a key role in the control of animal health. With the advancement of science, vaccines contain not only whole microorganisms (inactivated or attenuated) as active substances, but can also contain parts of microorganisms (recombinant proteins or synthetic peptides) obtained through a range of advanced technologies. The addition of an adjuvant enables a higher degree of vaccine safety, while also achieving better immunogenicity. Adjuvants in the form of aluminium salts are the most common in veterinary vaccines, and have been in use for decades. Other important adjuvants are in the form of emulsions, including mineral oils. The negative side of using mineral oils may be the occurrence of a local reaction at the administration site. Such changes may affect the slaughter value in fattening animals or competition or exhibition standings in show animals. These local reactions are often due to the viscosity of the adjuvant, and accordingly, mineral oils are not often used as an adjuvant in vaccines intended for humans and pets, but are mainly used for vaccination of farm animals. The development of new production technologies seeks to reduce the negative impacts on animals, and the possible reactions in people who use such vaccines. The package leaflet of vaccines containing mineral oil must contain a warning of the risks that may arise during administration and instructions on how to act in the event of an incident.

Key words: mineral oils; inactivated veterinary vaccines; adjuvants 